\title{
Comparison of Resin Infiltration Technique with Conventional Preventive Applications on Occlusal Fissures: EDS and SEM
} Analyses

\section{Usporedba tehnike infiltracije smolom poslije uporabe konvencionalnih preventivnih postupaka na okluzalnim fisurama s obzirom na kemijsku analizu i SEM}

\footnotetext{
${ }^{1}$ Private practice in Ankara, Turkey

Privatna ordinacija u Ankari, Turska

${ }^{2}$ Hacettepe University, School of Dentistry, Department of Restorative Dentistry, Ankara, Turkey

Zavod za restaurativnu stomatologiju Stomatološkog fakulteta Sveučilišta Hacettepe, Ankara, Turska
}

\section{Abstract}

Objective: To compare the subsurface mineral loss preventing capability of resin infiltration technique with topical fluoride and fissure sealant applications to demineralized occlusal fissures under simulated oral conditions. Materials and Methods: Occlusal surfaces of 64 extracted intact human third molars were demineralized. Next, the teeth were classified into four groups according to preventive applications ( $n=16)$ : G1, Specimens used as the control group with no preventive treatment; G2, Topical fluoride application (APF Gel/ DEEPAK); G3, Fissure sealant application (ClinproTMSealant/ 3M ESPE); and G4, Resin infiltration technique (Icon/ DMG). Chemical compositions before $\mathrm{pH}$ cycling were evaluated for eight specimens from each group. The remaining eight teeth from each group were subjected to $\mathrm{pH}$ cycling for 15 days to simulate the oral conditions. Subsequently, the specimens were fractured after immersion in liquid nitrogen and the subsurface fluoride (F), calcium $(\mathrm{Ca})$, phosphorus $(\mathrm{P})$ levels, and $\mathrm{Ca} / \mathrm{P}$ ratio of each specimen were measured using energy dispersive $x$-ray spectrometer (EDS). The data were subjected to statistical analysis $(p=0.05)$. The effects of preventive applications to surface topography of specimens were evaluated using scanning electron microscope (SEM). Results: There were no significant differences among the groups in subsurface $\mathrm{F}, \mathrm{Ca}$, and $\mathrm{P}$ levels and $\mathrm{Ca} / \mathrm{P}$ ratios before or after $\mathrm{pH}$ cycling $(\mathrm{p}>0.05)$. All three preventive applications were effective during $\mathrm{pH}$ cycling according to SEM observations. Conclusions: The subsurface mineral loss preventing capability of resin infiltration technique applied to occlusal fissures was comparable to topical fluoride and fissure sealant applications. Clinical significance: The resin infiltration technique could represent a valid alternative to traditionally used both preventive and restorative treatments for treating initial carious lesions on occlusal fissures, offering the advantages of better resin penetration and retention.
Received: February 8, 2020

Accepted: June 19, 2020

Address for correspondence Sidika Aynur Horuztepe, DDS, PhD Specialist in Restorative Dentistry at EOT Dental Clinic,

06680 / Cankaya Ankara-TURKEY Phone: +90 5336856625 ,

Fax: +903124274547

a.horuztepe@gmail.com

\section{Introduction}

Tooth decay is an infectious microbiological condition that results in local dissolution and calcified tissues destruction (1). It is experienced by more than two-thirds of all children and over $90 \%$ of all dentate adults in the United States, with a wide range of severity (2).

During caries formation, a clinically noticeable pore structure is formed by dissolving the minerals from the outer layer of the enamel, which is known as "white spot" lesions representing the earliest evidence of caries (3). These lesions are usually observed on the facial, lingual, and proximal smooth surfaces of the teeth and also on pits and occlusal fissures.
Uvod

Zubni karijes zarazno je mikrobiološko stanje koje rezultira lokalnim otapanjem i uništavanjem kalcificiranih tkiva (1). Događa se, u različitim stupnjevima težine, kod više od dvije trećine djece i više od $90 \%$ svih odraslih osoba u Sjedinjenim Američkim Državama (2).

Tijekom nastajanja karijesa stvara se klinički uočljiva porozna struktura zbog otapanja minerala vanjskoga sloja cakline, što je poznato kao bijela mrlja koja je najraniji dokaz karijesa (3). Te se lezije obično opažaju na glatkim vestibularnim, lingvalnim i aproksimalnim plohama zuba te na jamicama i okluzalnim fisurama. Okluzalne fisure su najosjetljivija mje- 
Occlusal fissures are the most vulnerable sites to caries lesions because of morphology and plaque accumulation $(4,5)$.

White spot lesions of enamel on the occlusal fissures and other areas are generally treated by increasing remineralization through fluoridation and ensuring oral hygiene improvement $(6,7)$ and by preventing the progression of the lesion with fissure sealant application (8).

Fluoride is one of the most important agents for the treatment of initial enamel lesions (4). It has become clear that when $\mathrm{F}$ ions are part of the remineralization process, the enamel integrity is restored and the enamel's resistance to further cariogenic attacks is increased (7). In comparison to smooth surface caries, flouride treatments could not totally occlude fissure and pit caries, making them less effective on these surfaces that are more prone to caries because of their morphological conditions (1).

Fissure sealant application is a non-invasive treatment option for occlusal surfaces with non-cavitated lesions acting as a mechanical barrier between enamel surface and biofilm formation, thereby preventing caries progression (8). Although fissure sealant resins were originally designed as a preventive measure, current studies show that the resin protects the initial porous lesions on altered occlusal surfaces due to demineralization from progression and formation of cavities (810). The main disadvantage of this method is the insufficient etching caused by phosphoric acid on deeper parts of the fissures and the inability of the viscous resins to completely cover the fissure surfaces $(1,11)$. Furthermore, an adequate barrier is not created inside the lesion, thereby possibly partially sealing the fissure, which also includes early caries and plaque, resulting in further caries progression $(11,12)$.

Lately, a low-viscosity resin that can penetrate into caries lesions, which is referred to as resin infiltration technique by Kielbassa et al., has been introduced (11). The mechanisms associated with this method depend on the infiltration of subsurface lesions with low-viscosity light-curing resins after eroding the highly mineralized surface layer and increasing penetration depth with a hydrochloric acid solution (11-13). This method is believed to overcome the limitations of topi$\mathrm{cal} \mathrm{F}$ and sealant applications and is considered to be a better alternative for the treatment of initial caries lesions (11). The effectiveness of resin infiltration technique on smooth surfaces has been widely examined $(3,6,11,12)$; however, there is less information about its preventive effect on fissures $(13,14)$.

The present study compared the changes in subsurface chemical composition of resin infiltrant, topical $\mathrm{F}$, and fissure sealant applied demineralized occlusal fissures after exposure to imitated oral conditions and evaluated the surface morphology of each specimen under a scanning electron microscope (SEM). Therefore, our hypothesis was that the protective properties of the resin infiltration technique in demineralized occlusal fissures are more effective than conventional topical $\mathrm{F}$ and fissure sealant applications.

\section{Material and methods}

Overall, 64 extracted healthy human third molars were used for this in vitro study. The collected teeth were disinfected in $10 \%$ formalin solution for 10 minutes, carefully sta za pojavu karijesnih lezija zbog morfologije i nakupljanja plaka $(4,5)$.

Bijele mrlje na caklini okluzalnih fisura i u drugim područjima općenito se liječe poticanjem remineralizacije fluoridacijom i boljom oralnom higijenom $(6,7)$ te sprječavanjem napredovanja lezije primjenom smola za pečaćenje fisura (8).

Fluor je jedno od najvažnijih sredstava za liječenje početnih lezija u caklini (4). Postalo je jasno da kada su ioni fluora dio procesa remineralizacije, obnavlja se integritet cakline i povećava njezina otpornost na daljnje kariogene napade (7). U usporedbi s karijesom na glatki površinama, aplikacija fluora nije mogla potpuno zabrtviti fisure i jamice, što ga čini manje učinkovitima na onim površinama koje su zbog svojih morfoloških uvjeta sklonije karijesu (1).

Primjena smola za pečaćenje fisura neinvazivna je opcija liječenja okluzalnih površina s nekavitiranim lezijama zato što djeluje kao mehanička barijera između površine cakline i stvaranja biofilma, čime se sprječava napredovanje karijesa (8). Iako su smole za pečaćenje fisura izvorno zamišljene kao preventivna mjera, aktualna istraživanja pokazuju da smola štiti od napredovanja i stvaranja kaviteta inicijalne porozne lezije na promijenjenim okluzalnim plohama zbog demineralizacije $(8,10)$. Glavni nedostatak te metode jest nedovoljno nagrizanje prouzročeno fosfornom kiselinom na dubljim dijelovima fisura i nemogućnost viskoznih smola da potpuno prekriju površinu fisura $(1,11)$. Nadalje, unutar lezije ne stvara se odgovarajuća barijera, čime se vjerojatno samo djelomično brtvi fisura koja također sadržava inicijalni karijes i plak, što rezultira daljnjim napredovanjem karijesa $(11,12)$.

Nedavno je predstavljena smola niske viskoznosti koja može prodrijeti u karijesne lezije, što je poznato kao tehnika infiltracije smole prema Kielbassiju i suradnicima (11). Mehanizmi povezani s tom metodom ovise o infiltraciji potpovršinskih lezija sa svjetlosno polimerizirajućim smolama male viskoznosti nakon erozije visokomineraliziranog površinskog sloja i povećanja dubine prodiranja otopinom klorovodične kiseline (11 13). Pretpostavlja se da ta metoda prevladava ograničenja topikalne primjene fluora i smola za pečaćenje, te se smatra boljom alternativom u liječenju početnih karijesnih lezija (11). Učinkovitost tehnike infiltracije smole na glatkim površinama detaljno je ispitivana $(3,6,11,12)$, no manje je podataka o njezinu preventivnom učinku na fisurama $(13,14)$.

U ovom su se istraživanju uspoređivale promjene u kemijskom sastavu ispod površine nakon infiltracije smolom i topikalne primjene fluora i smole za pečaćenje fisura na demineraliziranim okluzalnim fisurama poslije izlaganja, radi oponašanja intraoralnih uvjeta te se procjenjivala površinska morfologija svakog uzorka pod skenirajućim elektronskim mikroskopom (SEM). Zato je naša hipoteza bila da su zaštitna svojstva infiltracijske tehnike u demineraliziranim okluzalnim fisurama učinkovitija od uobičajene topikalne primjene fluora i smola za pečaćenje fisura.

\section{Materijali i metode}

Ukupno su za ovo istraživanje in vitro upotrijebljena 64 izvađena zdrava ljudska umnjaka. Zubi su 10 minuta dezinficirani u 10-postotnoj otopini formalina, pažljivo očišćeni 
cleaned from the soft tissue, and stored in distilled water at room temperature until required for use. The root apices were sealed with epoxy resin, and all tooth surfaces, excluding the occlusal surfaces, were coated with two layers of nail polish. The occlusal surfaces of the teeth were demineralized by immersion in $8 \mathrm{ml}$ of demineralization solution for 72 hours at $37^{\circ} \mathrm{C}$, according to the protocol used by Ten Cate and Duijsters (15). Subsequently, the teeth were rinsed with an air/water spray for 5 seconds, dried with oil-free compressed air, and randomly assigned to four groups according to the preventive applications used $(\mathrm{n}=16)$ :

G1: These specimens were used as controls and no preventive treatment was applied.

G2: The teeth were desiccated by air blowing and an acidulated phosphate F (APF) gel (APF Gel; DEEPAK, Miami, FL, USA) that contains $1.23 \% \mathrm{~F}$ ion, which was applied onto the occlusal fissures with sponge applicators. After 4 minutes, the gel was removed using cotton rolls and the teeth were rinsed/dried with air/water spray.

G3: The teeth were dried with an air-water spray, etched for 30 seconds with 37\% phosphoric acid gel (Etchant gel, PrimeDent, Chicago, IL, USA), and rinsed and air dried with compressed air for 20 and 10 seconds respectively. A light-cured and low-viscosity pit and fissure sealant (Clinpro ${ }^{\mathrm{TM}}$ Sealant/ $3 \mathrm{M}$ ESPE, St Paul, MN, USA) was applied onto the fissures along their entire extension with the tip of a probe to prevent air entrapment. Then the resin sealant was light-cured for 20 seconds using LED-curing unit (Radii Plus, SDI, Victoria, Australia).

G4: The specimens were dried with oil-free compressed air. Hydrochloric acid ( $\mathrm{HCl}$ ) etching gel (Icon etch, DMG, Hamburg, Germany) was applied with a syringe on fissures and left undisturbed for 2 minutes and the gel was rinsed with air-water spray for 30 seconds. Subsequently, 99\% ethanol (Icon Dry, DMG, Hamburg, Germany) was applied for 10 seconds, and the specimens were air dried again for 10 seconds. Next, the infiltrant (Icon infiltrant, DMG, Hamburg, Germany) was applied with gentle agitation. After 3 minutes of penetration time, any excess material was removed by air blowing and the resin was light-cured for 40 seconds using LED-curing unit. The infiltration step was repeated for 1 minute to infiltrate remaining porosity followed by light curing for 40 seconds.

After completing the preventive applications according to the manufacturers' instructions, the groups were divided into two subgroups. Eight specimens from each group were kept for evaluation of element levels, and the other eight teeth were subjected to $\mathrm{pH}$ cycling to mimic oral conditions $(15,16)$. The $\mathrm{pH}$ cycling regime reported in previous studies was designed to approach the $\mathrm{pH}$ dynamics of the oral environment (Table 1) (16). The regimen was repeated for 15 days at $37^{\circ} \mathrm{C}$, and the temperature was maintained by means of an incubator. The specimens were washed with distilled water and dried with oil-free compressed air between transfers from deminerelizing and remineralizing solutions. The dereminerilizing and remineralizing solutions were refreshed every 3 days throughout the experimental period (17).

Next, the specimens were cross-sectioned perpendicular to occlusal surfaces. To obtain a clear sagittal view, vertical slits spanning from apical to the cement-enamel junction were cut od mekoga tkiva i do upotrebe pohranjeni u destiliranoj vodi na sobnoj temperaturi. Vrhovi korijena zapečaćeni su epoksidnom smolom, a sve površine zuba, osim okluzalnih, premazane su dvama slojevima laka za nokte. Okluzalne plohe zuba demineralizirane su potapanjem u $8 \mathrm{~mL}$ otopine za demineralizaciju tijekom 72 sata na $37^{\circ} \mathrm{C}$, prema protokolu koji su primijenili Ten Cate i Duijsters (15). Poslije toga zubi su 5 sekunda ispirani sprejom zrak - voda, osušeni komprimiranim zrakom bez ulja i nasumično uvršteni u jednu od četiriju skupina prema primijenjenim preventivnim primjenama $(\mathrm{n}=16)$ :

G1 - ti su uzorci korišteni kao kontrola i nije proveden preventivni postupak

G2 - zubi su osušeni zrakom te je na okluzalne fisure aplikatorom nanesen kiseli fosfatno-fluoridni (APF) gel (APF Gel; DEEPAK, Miami, FL, SAD) koji sadržava 1,23\% iona fluora. Nakon četiri minute gel je uklonjen pamučnim kuglicama, a zubi isprani i osušeni.

G3 - zubi su osušeni, jetkani 30 sekunda 3-postotnimim gelom fosforne kiseline (Etchant gel, Prime-Dent, Chicago, IL, SAD) nakon čega su 20 sekunda ispirani i zatim osušeni komprimiranim zrakom 10 sekunda. Na fisure je cijelom duljinom vrhom sonde nanesena svjetlosno polimerizirajuća smola za pečaćenje niske viskoznosti (ClinproTM Sealant/3M ESPE, St Paul, MN, SAD) da bi se spriječile inkluzije zraka. Zatim se smola osvijetlila 20 sekunda polimerizacijskom LED svjetiljkom (Radii Plus, SDI, Victoria, Australija).

G4 - uzorci su osušeni komprimiranim zrakom bez ulja. Gel za jetkanje na bazi klorovodične kiseline (HCl) (Icon etch, DMG, Hamburg, Njemačka) nanesen je štrcaljkom na fisure i ostavljen da djeluje dvije minute, nakon čega je 30 sekunda ispiran sprejom zrak - voda. Poslije toga je apliciran 99-postotni etanol (Icon Dry, DMG, Hamburg, Njemačka) tijekom 10 sekunda, a uzorci su ponovno sušeni na zraku 10 sekunda. Zatim je aplicirana infiltracijska smola (Icon infiltrant, DMG, Hamburg, Njemačka). Nakon trominutne infiltracije, sav višak materijala uklonjen je ispuhivanjem zrakom i smola je polimerizirana svjetlošću 40 sekunda s pomoću LED svjetiljke. Postupak infiltracije ponovljen je još jednu minutu da bi se infiltrirala preostala porozna područja, nakon čega je slijedila 40-sekundna svjetlosna polimerizacija.

Nakon što su dovršeni preventivni postupci prema uputama proizvođača, skupine su podijeljene u dvije podskupine. Osam uzoraka iz svake skupine čuvalo se za procjenu razine elemenata, a ostalih osam podvrgnuto je cikliranju $\mathrm{pH}$ kako bi se oponašali intraoralni uvjeti $(15,16)$. Režim cikliranja $\mathrm{pH}$ koji je provođen u ranijim istraživanjima osmišljen je da bi se simulirala dinamika $\mathrm{pH}$ u oralnom okružju (tablica 1.) (16). Ponavljao se 15 dana pri $37^{\circ} \mathrm{C}$, a temperatura se održavala s pomoću inkubatora. Uzorci su isprani destiliranom vodom i osušeni komprimiranim zrakom bez ulja između prijenosa iz demineralizirajuće i remineralizirajuće otopine. Otopine za demineralizaciju i remineralizaciju osvježavale su se svaka tri dana tijekom eksperimentalnog razdoblja (17).

Nakon toga uzorci su prerezani okomito na okluzijske površine. Da bi se dobio jasan sagitalni prikaz, na svakom zubu urezani su dijamantnom pilom male brzine (Isomet Low Speed Saw, Buehler, Lake Bluff, IL, SAD) vertikalni prorezi 
Table 1 The $\mathrm{pH}$ cycling model used in the study

Tablica 1. Model cikliranja pH primijenjen u istraživanju

\begin{tabular}{c|c} 
Time $\bullet$ Vrijeme & Experimental solution $\bullet$ Eksperimentalna otopina \\
\hline 8:00 a.m.-11:00 a.m. & Remineralization solution $\bullet$ Remineralizacijska otopina \\
\hline 11:00 a.m.-1:00 p.m. & Demineralization solution $\bullet$ Demineralizacijska otopina \\
\hline 1:00 p.m.-8:00 a.m. & Remineralization solution $\bullet$ Remineralizacijska otopina
\end{tabular}

Remineralization solution • Remineralizacijska otopina: ( $\mathrm{pH}$ 7), $20 \mathrm{mmol}$ l-1 HEPES, $1.5 \mathrm{mM} \mathrm{CaCl}_{2} 0.9 \mathrm{mM} \mathrm{KH}_{2} \mathrm{PO}_{4}, 130 \mathrm{mM} \mathrm{KCl}, 1 \mathrm{mM} \mathrm{NaN}$ Demineralization solution • Demineralizacijska otopina: ( $\mathrm{pH}$ 4.5) $50 \mathrm{mM}$ Acetic Acid, $2.2 \mathrm{mM} \mathrm{Ca}\left(\mathrm{NO}_{3}\right)_{2}, 2.2 \mathrm{mM} \mathrm{KH}_{2} \mathrm{PO}_{4}, 0.1 \mathrm{ppm} \mathrm{NaF}$.

on each tooth with a low speed diamond saw (Isomet Low Speed Saw, Buehler, Lake Bluff, IL, USA) leaving the occlusal side untouched. After the immersion in liquid nitrogen for 2 minutes, the specimens were gently fractured along the preformed slits with a hammer and scalpel blade (18). The subsurface $\mathrm{F}(\mathrm{F})$, calcium $(\mathrm{Ca})$, and phosphorus $(\mathrm{P})$ levels and $\mathrm{Ca} / \mathrm{P}$ ratio of each specimen were measured using energy dispersive spectrometer (Bruker Axs XFlash 3001 SDD-EDS, Cambridge, UK). Three measurements were taken from each specimen and the mean values for each specimen were individually calculated. The data were analyzed statistically using the SPSS 13.0 software for the changes in subsurface element levels among the groups before and after $\mathrm{pH}$ cycling with the One-Way ANOVA or Kruskal Wallis tests according to the normality of the data for each element. The comparisons of each individual group before and after $\mathrm{pH}$ cycling were evaluated using the $\mathrm{t}$-test. The statistical significance level for each test was set at $p=0.05$.

The surface topography of all the specimens was evaluated under SEM (Zeiss EVO 50 EP SEM, Carl Zeiss, Cambridge, UK) with $1000 \mathrm{X}$ magnification. Acceleration voltage was $20 \mathrm{kV}$ using a backscattered electron detector (BSE). The images were obtained at an extended variable pressure (XVP) mode without coating since the vacuuming conditions needed to sputter the fragile enamel specimens might have resulted in deterioration on the surfaces.

\section{Results}

The $\mathrm{P}, \mathrm{Ca}$ levels and $\mathrm{Ca} / \mathrm{P}$ ratios among the groups were not statistically significant before or after $\mathrm{pH}$ cycling $(\mathrm{p}>$ 0.05). Although, the topical F applied group (G2) tended to exhibit an increased trend in F level, the differences among the groups were not significant $(p>0.05)$. A comparison of $\mathrm{F}, \mathrm{P}$, and $\mathrm{Ca}$ levels and $\mathrm{Ca} / \mathrm{P}$ ratios within each group before and after $\mathrm{pH}$ cycling revealed no significant differences $(\mathrm{p}>$ $0.05)$. Table 2 gives summary of the obtained results. od vrha do cementno-caklinskog spojišta ostavljajući okluzalnu stranu intaktnom. Nakon dvominutnog uranjanja u tekući dušik uzorci su nježno prelomljeni duž ranije oblikovanih proreza čekićem i oštricom skalpela (18). Razine fluora $(\mathrm{F})$, kalcija $(\mathrm{Ca})$ i fosfora $(\mathrm{P})$ te omjer $\mathrm{Ca} / \mathrm{P}-\mathrm{a}$ svakog uzorka izmjereni su energijsko disperzivnim spektrometrom (Bruker Axs XFlash 3001 SDD-EDS, Cambridge, UK). Na svakom uzorku provedena su tri mjerenja, a srednje vrijednosti za svaki uzorak izračunate su pojedinačno. Podatci su statistički analizirani u softveru SPSS 13.0 da bi se ustanovile promjene u razinama elemenata ispod površine među skupinama prije cikliranja $\mathrm{pH}$ i poslije toga postupka jednosmjernim ANOVA testom ili Kruskal-Wallisovim testovima prema normalnosti podataka za svaki element. Usporedbe svake skupine prije cikliranja $\mathrm{pH}$ i poslije toga postupka procijenjene su t-testom. Razina statističke značajnosti za svaki test bila je postavljena na $\mathrm{p}=0,05$.

Topografija površine svih uzoraka procijenjena je pod SEM-om (Zeiss EVO 50 EP SEM, Carl Zeiss, Cambridge, UK) s povećanjem od 1000 puta. Napon ubrzanja bio je 20 $\mathrm{kV}$, uz povratno raspršeni elektronski detektor (BSE). Slike su dobivene u načinu produženoga promjenjivog tlaka (XVP) bez nanošenja premaza jer bi usisavanje koje je potrebno za raspršivanje krhkih uzoraka cakline moglo oštetiti površinu.

\section{Rezultati}

Razine fosfora, kalcija i omjeri $\mathrm{Ca} / \mathrm{P}$-a među skupinama nisu bili statistički značajno različiti prije cikliranja $\mathrm{pH}$ ili poslije toga postupka $(\mathrm{p}>0,05)$. Iako je skupina s topikalnom primjenom fluora $(\mathrm{G} 2)$ imala tendenciju povećavanja razine fluora, razlike među skupinama nisu bile statistički značajne $(p>0,05)$. Usporedba razina fluora, fosfora i kalcija te omjera $\mathrm{Ca} / \mathrm{P}-\mathrm{a}$ unutar svake skupine prije cikliranja $\mathrm{pH}$ i poslije toga postupka, nije pokazala statistički značajne razlike $(\mathrm{p}>0,05)$. U tablici 2 je sažetak dobivenih rezultata.

Table 2 Subsurface Element Levels (\%) of the Specimens (Mean \pm SD)

Tablica 2. Razine elemenata ispod površine (\%) uzoraka (Mean \pm S D)

\begin{tabular}{|c|c|c|c|c|c|c|c|c|c|c|}
\hline$\%$ & & No pH Cyclir & g • Bez ciklir & nja pH & & & pH Cycli & g • Cikliranje & pH & \\
\hline $\begin{array}{c}\text { Elements • } \\
\text { Elementi }\end{array}$ & G 1 & G 2 & G 3 & G 4 & p & G 1 & G 2 & G 3 & G 4 & p \\
\hline F & $0.68 \pm 1.25$ & $1.53 \pm 1.18$ & $0.87 \pm 0,97$ & $1.28 \pm 1.59$ & 0.54 & $0.96 \pm 1.69$ & $1.79 \pm 1.55$ & $0.47 \pm 0.63$ & $1.68 \pm 2.17$ & 0.33 \\
\hline $\mathbf{P}$ & $16.29 \pm 1.04$ & $16.16 \pm 0.97$ & $16.29 \pm 1.02$ & $15.34 \pm 1.60$ & 0.28 & $15.41 \pm 1.81$ & $14.99 \pm 1.56$ & $15.96 \pm 1.34$ & $15.06 \pm 1.98$ & 0.65 \\
\hline $\mathrm{Ca}$ & $37.59 \pm 3.65$ & $35.94 \pm 2.29$ & $38.38 \pm 4.09$ & $36.76 \pm 4.85$ & 0.62 & $38.36 \pm 5.23$ & $36.64 \pm 8.59$ & $37.40 \pm 2.21$ & $34.80 \pm 5.36$ & 0.66 \\
\hline $\mathrm{Ca} / \mathrm{P}$ & $2.31 \pm 0.24$ & $2.39 \pm 0.24$ & $2.36 \pm 0.30$ & $2.22 \pm 0.12$ & 0.85 & $2.40 \pm 0.30$ & $2.46 \pm 0.30$ & $2.35 \pm 0.27$ & $2.31 \pm 0.17$ & 0.83 \\
\hline
\end{tabular}

$\mathrm{p}$ values indicate the results of Kruskal Wallis or One-Way ANOVA tests $(\mathrm{p}=.05) \cdot \mathrm{p}$ vrijednosti pokazuju rezultate Kruskal-Wallisova ili jednosmjernoga ANOVA testa $(p=0,05)$ 

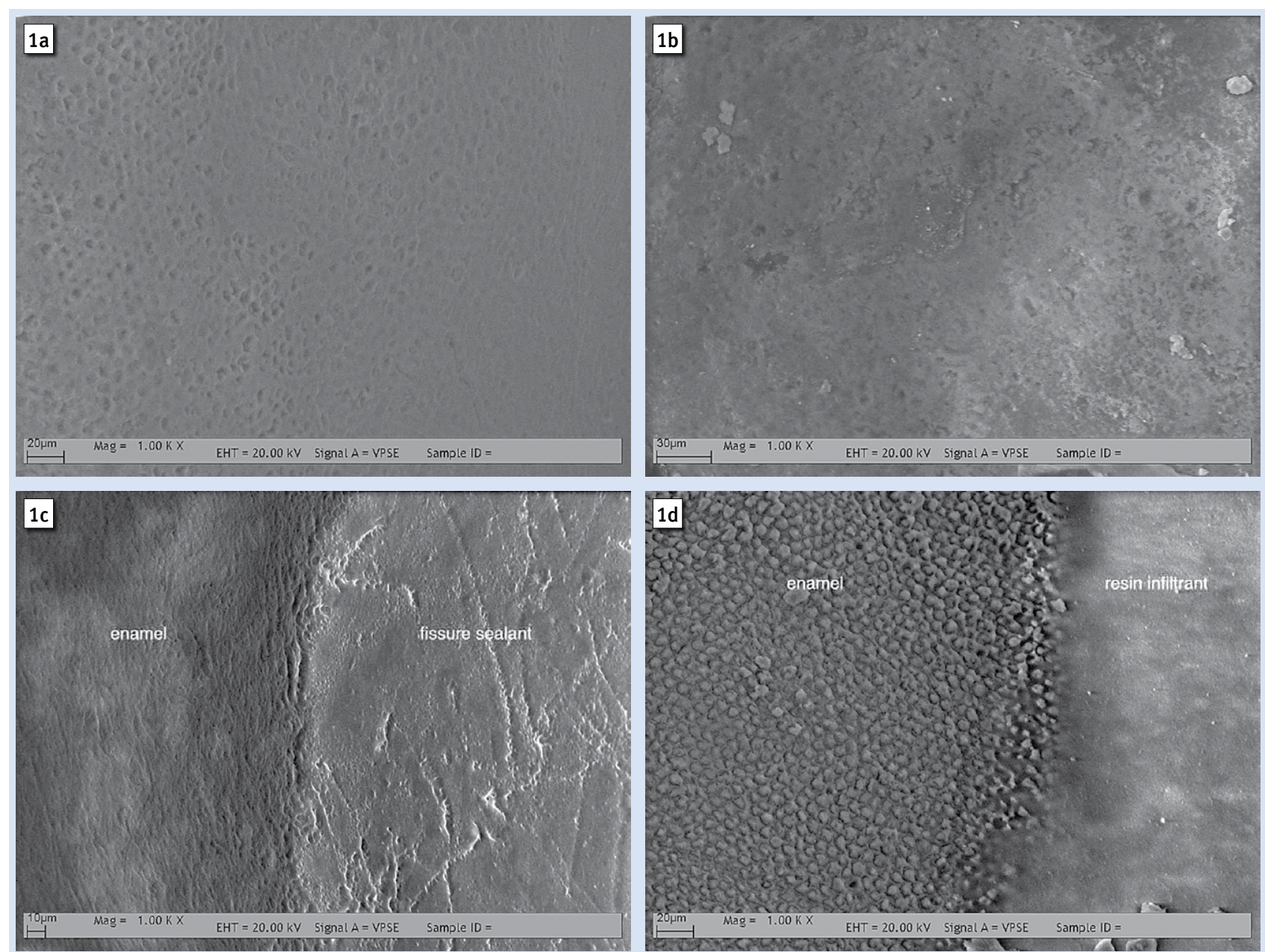

Figure 1 Representative scanning electron microscope views of the specimens before pH cycling (1000x). (1a) Demineralized enamel surface (control). Porous surface structure demonstrating a honeycomb-shape surface morphology is slightly observed. (G1); (1b) F applied enamel surface. The precipitation of amorphous structure on the porous enamel surface is observed. (G2); (1c) Fissure sealant applied enamel surface. The fissure sealant distinctly demarcates from the adjacent unsealed enamel and is slightly raised from the nearby enamel surface. (G3); (1d) Resin infiltrated enamel surface. The occlusal enamel-resin infiltrant interface shows a smooth transition without gaps (G4).

Slika 1. Reprezentativni prikazi skenirajućeg elektronskog mikroskopa na uzorcima prije cikliranja pH (1000 x). (1a) Demineralizirana površina cakline (kontrola). Uočava se porozna površinska struktura s morfologijom u obliku saća (Gl); (1b) Površina cakline s nanesenim fluorom. Primjećuju se precipitati amorfne strukture na poroznoj površini cakline (G2); (1c) Površina cakline s nanesenom smolom za pečaćenje fisura. Postoji razlika između područja tretiranog smolom za pečaćenje i susjedne nezapečaćene cakline; površina je malo uzdignuta u odnosu prema okolnoj caklini (G3); (1d) Površina cakline infiltrirana smolom. Sučelje infiltrirane i netretirane cakline na okluzalnoj plohi ima glatki prijelaz bez šupljina (G4).

SEM observations revealed different morphological characteristics with different treatment approaches and $\mathrm{pH}$ cycling. After $\mathrm{pH}$ cycling, obvious deleterious effects were observed on enamel surfaces of occlusal fissures in G1, in which no preventive treatment was applied. The specimens treated with F (G2) or fissure sealant (G3) revealed slight changes on their morphological features, whereas there were no differences on the surface topography of the resin infiltration applied specimens (G4). Representative SEM images from each group are shown in Figures 1,2.

\section{Discussion}

This study has determined whether infiltration of a lowviscosity light-curing resin could be an alternative method to fissure sealant and topical $\mathrm{F}$ applications for the prevention of mineral loss of initial fissure caries lesions. For this purpose, ca-
SEM analizom otkrivene su različita morfološka obilježja s obzirom na različite postupke tretiranja površine i cikliranje $\mathrm{pH}$. Nakon cikliranja $\mathrm{pH}$ uočeni su očiti štetni učinci na površine cakline okluzalnih fisura u skupini G1 u kojoj nije primijenjen preventivni postupak. Na uzorcima tretiranima fluorom (G2) ili smolom za pečaćenje (G3), zabilježene su male promjene u morfološkim značajkama, a nije bilo razlika u površinskoj topografiji uzoraka infiltriranih smolom (G4). Reprezentativni SEM skenovi iz svake skupine prikazani su na slikama 1 i 2.

\section{Rasprava}

U ovom se istraživanju pokušalo ustanoviti može li infiltracija svjetlosno polimerizirajućom smolom niske viskoznosti biti alternativna metoda klasičnom pečaćenju fisura i topikalnoj primjeni fluora u prevenciji gubitka minerala u 

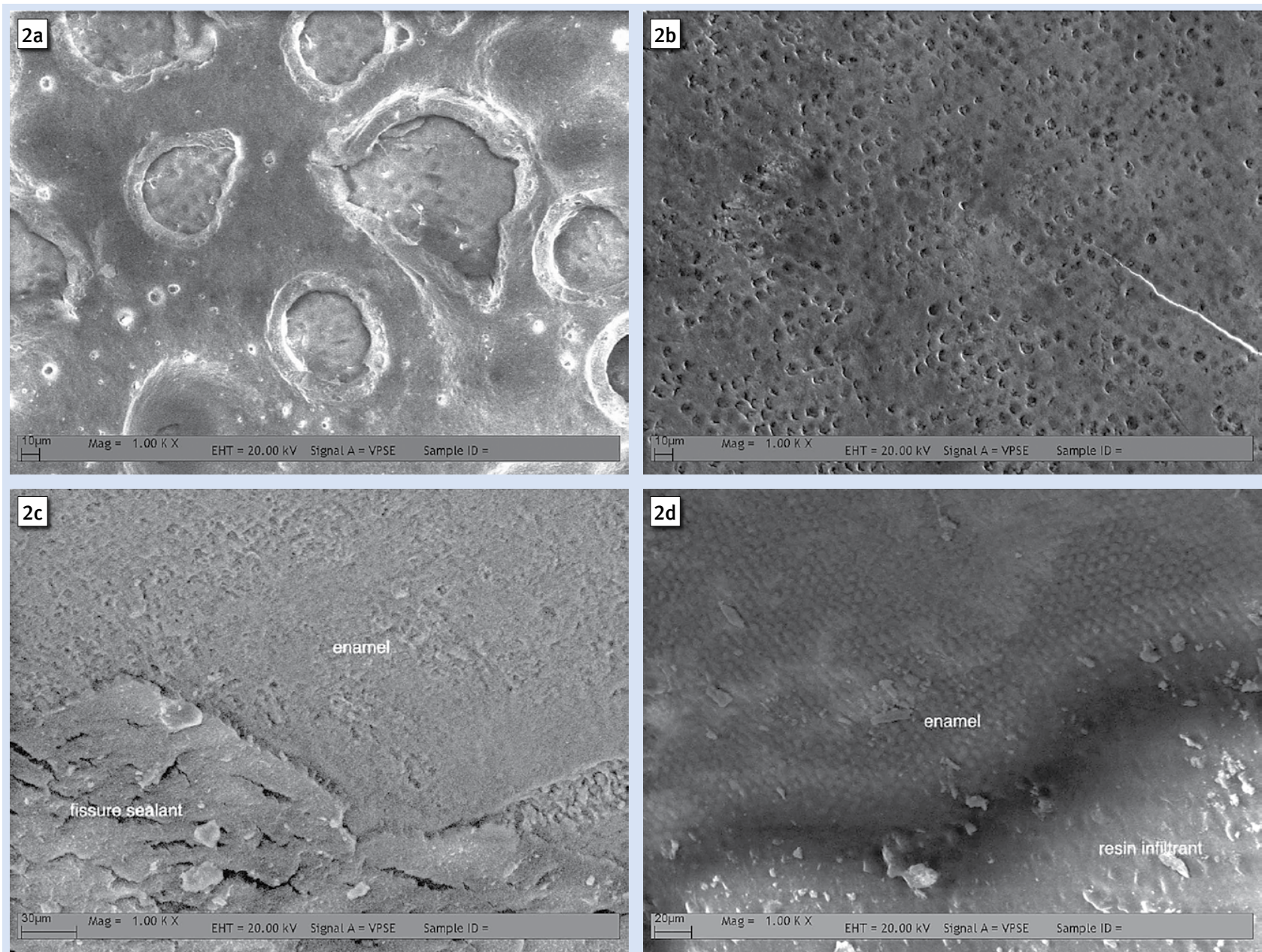

Figure 2 Scanning electron microscope views of the specimens after pH cycling (1000x). (2a) Demineralized enamel (control). Areas of superficial hypermineralized enamel erosion, characterized by an evident "localized peeling" of the surface, were observed (G1); (2b) F applied enamel surface. The appearance of honeycomb-shaped enamel, in which the prismatic orifices resulting from the $\mathrm{pH}$ cycling become more visible, is observed (G2); (2c) Fissure sealant applied enamel surface. An increased micro-gap is observed indicating that the junction between the fissure sealant and the adjacent enamel is weakened. It is also seen that the structure of the fissure sealant resin is deteriorated as microfracture (G3); (2d) Resin infiltrated enamel surface. An intact, interdigitating interface without micro-gaps between the resin infiltrant and the adjacent enamel is still observed. No deleterious effects of pH cycle on neighboring enamel are identified (G4).

Slika 2. Prikazi uzoraka pod skenirajućim elektronskim mikroskopom poslije ciklirana pH (1000 x) (2a) Demineralizirana caklina (kontrola). Uočena su područja površinske hipermineralizacije cakline karakterizirane lokaliziranim ljuštenjem površine (G1); (2b) Površina cakline s nanesenim fluorom. Uočava se morfologija cakline u obliku saća kod koje prizmatski otvori koji nastaju cikliranjem pH postaju vidljiviji (G2); (2c) Površina cakline s nanesenom smolom za pečaćenje fisura. Primjećuje se povećana mikropukotina što upućuje na to da je spoj između smole za pečećenje i susjedne cakline oslabljen. Također se vidi da je struktura smole za pečaćenje fisura oštećena (G3); (2d) Površina cakline infiltrirana smolom. Još uvijek se opaža intaktno sučelje s interdigitacijama, bez šupljina između smole i cakline. Nisu utvrđeni štetni učinci cikliranja pH na okolnu caklinu (G4).

ries-like artificial demineralization lesions were created using a similar technique mentioned in a previous in vitro study (17).

Although, the difference between artificial demineralization lesions and natural caries lesions may be a limitation to reflect the clinical conditions, our aim was to create standard demineralization lesions to prevent any negative effects that may arise from the heterogeneity of the specimens $(13,17)$. It is known that an initial caries lesion in the enamel is softer than the surrounding sound tissue and is visible as white spots with increased opacity when air dried (1). There is a consensus in the literature that the basic attributes that characterize these lesions include a relatively intact, mineral-rich surface layer and a subsurface demineralized area that can be observed when the cross-section of the lesion is formed from the initial caries $(1,19)$. početnim karijesnim lezijama fisura. $U$ tu svrhu umjetno su stvorene demineralizacijske lezije slične karijesu tehnikom spomenutom u ranijem istraživanju in vitro (17).

Iako razlika između umjetnih demineralizacijskih lezija i prirodnog karijesa može biti ograničenje u oponašanju kliničkih uvjeta, cilj nam je bio stvoriti standardne demineralizacijske lezije kako bismo spriječili bilo kakve negativne učinke koji mogu nastati zbog heterogenosti uzoraka (13, 17). Poznato je da je početna karijesna lezija cakline mekša od okolnoga zdravoga zubnog tkiva i vidljiva je kao bijela mrlja s povećanom neprozirnošću kada se osuši strujom zraka (1).

U literaturi postoji konsenzus o tome da osnovna obilježja koja karakteriziraju te lezije uključuju razmjerno intaktni površinski sloj bogat mineralima i demineralizirano područje 
In the present study, the subsurface element levels were evaluated because the demineralization in initial caries lesions is mostly pronounced in the subsurface layer according to the "phenomenon of subsurface demineralization" as mentioned previously (20). To evaluate the subsurface demineralization, the specimens were flash frozen by immersion in liquid nitrogen and fractured along the pre-formed slits to obtain clear and untouched cross-sections. It is also important to emphasize that all the native elements of enamel could be retained without any alteration in the specimens because of the rapid freeze procedure and the fact that the subsequent management of specimens was without the use of water (18).

The levels of $\mathrm{Ca}$ and $\mathrm{P}$, the major components of enamel, indicate demineralization, and $\mathrm{F}$ is another important element that could reduce the solubility of calcium phosphate (21). Therefore, the present study evaluated the subsurface $\mathrm{F}, \mathrm{P}$, and $\mathrm{Ca}$ levels and $\mathrm{Ca} / \mathrm{P}$ ratio using $\mathrm{EDS}$, which represents a specific method for determining the concentration of chemical elements of the materials both on the surface and subsurface (22). There are several methods to evaluate demineralization process on enamel, such as microradiography (23), polarized light microscopy (24), X-Ray Photoelectron Spectroscopy (XPS) (22), and Raman spectroscopy (22). Furthermore, the X-ray energy dispersive spectroscopy (EDS) analysis is a qualitative and quantitative method to determine chemical elements compositions in various samples (22). This system bombards the sample with a high-voltage electron beam that emits a characteristic wavelength for each mineral and works by showing rays of different wavelengths that are reflected back depending on the specific mineral concentration in the sample (25). The sensitivity of this technique changes depending on the method of sample preparation for microanalysis and the atomic number of all elements found in the specimens, particularly the atomic number of the element to be identified (22). The atomic numbers of $\mathrm{Ca}, \mathrm{P}$, and $\mathrm{F}$ elements which were evaluated in the present study are 20,25, and 9, respectively and the quantitative sensitivity of EDS evaluation is higher for $\mathrm{Ca}$ and $\mathrm{P}$ than $\mathrm{F}$ because they possess higher atomic numbers (22). Although there have been some concerns about the efficacy of this method for analyzing the elements with lower atomic number, such as F, previously, the current SEM-EDS systems can adequately analyze such elements too (26).

Therefore, the EDS method was particularly preferred in this study for providing a certain advantage of reliable and non destructive analysis of the fragile enamel samples.

There are limited data in the literature about the effect of resin infiltrant application on enamel element levels. Gelani et al tested the ability of resin infiltrant and $\mathrm{F}$ application on preventing subsurface mineral loss of the artificial enamel carious lesion with the EDS and they observed less mineral loss in the groups treated with resin infiltrants than in those only treated with F (27). Similar to this study, the results of our experiment indicated some slight changes in $\mathrm{F}, \mathrm{Ca}$, and $\mathrm{P}$ levels and $\mathrm{Ca} / \mathrm{P}$ ratio after $\mathrm{pH}$ cycling in all groups. However, the differences were not statistically significant.

Remineralization and arrest of initial caries lesions by topical $\mathrm{F}$ applications and fissure sealants have been investigated ispod površine koje se može uočiti kada se napravi presjek lezije početnog karijesa $(1,19)$.

$\mathrm{U}$ ovom su istraživanju procijenjene razine elemenata ispod površine jer se demineralizacija u početnim karijesnim lezijama uglavnom pojavljuje u tom sloju u skladu s fenomenom demineralizacije ispod površine, kako je već spomenuto (20). Da bi se procijenila demineralizacija ispod površine, uzorci su naglo zamrznuti uranjanjem u tekući dušik i prelomljeni duž unaprijed oblikovanih proreza kako bi se dobili jasni i intaktni presjeci. Također je važno istaknuti da se svi nativni elementi cakline mogu zadržati bez ikakvih promjena u uzorcima zbog postupka brzog zamrzavanja i činjenice da je naknadno tretiranje uzoraka bilo bez upotrebe vode (18).

Razine kalcija i fluora, glavnih komponenata cakline, upućuju na demineralizaciju, a fosfor je drugi važan element koji bi mogao smanjiti topljivost kalcijeva fosfata (21). Zato su se u ovom istraživanju procjenjivale razine fluora, fosfora i kalcija te omjer Ca/P-a ispod površine s pomoću EDS-a, koji je specifična metodu za određivanje koncentracije kemijskih elemenata materijala na površini i ispod nje (22). Nekoliko je metoda za procjenu procesa demineralizacije na caklini, poput mikroradiografije (23), mikroskopije polariziranog svjetla (24), rendgenske fotoelektronske spektroskopije (XPS) (22) i Ramanove spektroskopije (22). Nadalje, analiza rendgenskom disperzivnom spektroskopijom (EDS) kvalitativna je i kvantitativna metoda za određivanje sastava kemijskih elemenata u različitim uzorcima (22). Tim se sustavom uzorak bombardira visokonaponskim elektronskim snopom koji emitira karakterističnu valnu duljinu za svaki mineral i djeluje tako da pokazuje zrake različitih valnih duljina koje se reflektiraju natrag, ovisno o specifičnoj koncentraciji minerala u uzorku (25). Osjetljivost te tehnike mijenja se ovisno o metodi pripreme uzorka za mikroanalizu i atomskom broju svih elemenata koji se nalaze u uzorcima, posebno atomskom broju elementa koji treba identificirati (22). Atomski brojevi elemenata $\mathrm{Ca}, \mathrm{P}$ i F, koji su procijenjeni u ovom istraživanju, iznose 20, 25, odnosno 9, a kvantitativna osjetljivost procjene EDS-a veća je za kalcij i fosfor od fluora jer imaju veće atomske brojeve (22 ). Iako je prije postojala određena sumnja u učinkovitost te metode za analizu elemenata s nižim atomskim brojem, poput fluora, sadašnji SEM-EDS sustavi mogu adekvatno analizirati i takve elemente (26).

Zato je EDS posebno pogodna metoda za ovo istraživanje jer omogućuje pouzdanu i nedestruktivnu analize krhkih uzoraka cakline.

U literaturi su ograničeni podatci o učinku infiltracije smolom na razinu elemenata u caklini. Gelani i suradnici testirali su EDS-om svojstvo infiltracije smolom i primjenu fluora da spriječe gubitak minerala ispod površine u umjetnoj karijesnoj leziji cakline, te su primijetili manji gubitak minerala u skupinama tretiranima infiltracijom smolom negoli u onima gdje je apliciran fluor (27). Slično tom istraživanju, rezultati našeg eksperimenta upućivali su na neke male promjene u razinama fluora, kalcija i fosfora te u omjeru $\mathrm{Ca} / \mathrm{P}-\mathrm{a}$ nakon cikliranja $\mathrm{pH}$ u svim skupinama. No, razlike nisu bile statistički značajne.

Remineralizacija i zaustavljanje početnih karijesnih lezija topikalnom primjenom fluora i smolama za pečaćenje fisura 
in several studies $(7,8,10,16,28)$. However, at the initial caries stage of the enamel lesion, $\mathrm{F}$ may be effective in remineralizing the outer "surface layer," which is sealed off, thereby impeding the penetration and repairal of deeper enamel lesions by calcium and phosphate (29). In addition, fissure sealants can only show superficial penetration into enamel lesions because they are not optimized for high penetrability (11). Since fissure sealant and $\mathrm{F}$ treatments can only affect the superficial region of the lesion, the dissolution of the porous structure in the subsurface lesion, which acts as a diffusion path for acids and minerals, cannot be prevented. Therefore, the infiltration technique of initial caries lesions with a low-viscous resin material has been considered as a micro invasive completion to these widely used preventive treatments $(8,11,13)$.

The resin infiltration technique has been developed to stop the progress of caries by filling the porous structure of the initial caries lesions with a light- cured low-viscosity resin (11). Compared to fissure sealants, resin infiltrants show rapid capillary penetration as low-viscosity materials that form a low contact angle with enamel because of their high surface energy $(3,11)$. Moreover, contrary to the fact that fissure sealants remain only on the surface of the enamel as a diffusion barrier, the resin infiltration materials form a diffusion barrier in the enamel lesion and strengthen the demineralized enamel structure by replacing the lost mineral with a low-viscosity light-curing resin $(6,11)$.

The effectiveness of resin infiltration to prevent the progression of smooth surface caries lesions has been investigated in vitro (30), in situ (31), and in vivo (32) studies. Paris et al. (33) showed with a micro radiographic technique that, a low-viscosity resin was able to inhibit the progression of natural flat surface enamel caries lesions after 400 days storage at $\mathrm{pH}$ 4.95. They also reported in another study that resin infiltration was effective to prevent further demineralization of artificial smooth surface enamel caries lesions under acidic situations in situ (31). An in vivo study comparing the effect of resin infiltration of proximal lesions with non-operative measures has found that the infiltration of interproximal caries lesions was effective in reducing lesion progression (32). Since previous studies $(6,12,30-33)$ have only evaluated the effect on smooth surfaces, it is not appropriate to compare these results in this study. There are only a few studies evaluating the efficacy of resin infiltration technique on occlusal surfaces and these studies have only evaluated the penetration of resin infiltrants $(13,14,34)$. In addition, to our knowledge, no study has reported about the behavior of infiltrated lesions and the effects of thin resin layers on lesion surfaces and the neighboring healthy enamel.

In the present study, the surface morphology of the specimens was also evaluated using the SEM. In our study, all the preventive applications were effective to eliminate neighboring enamel destruction on some level when compared to the control group. The resin infiltration method was one step forward for reducing demineralization on the neighboring enamel compared to the conventional sealant and F application, since enamel demineralization was much milder on the SEM image of the infiltrated sample. This finding is in line with numerous in vitro studies reported by others $(11,13,14,27,34)$. istraženi su u nekoliko istraživanja $(7,8,10,16,28)$. No u početnoj fazi karijesne lezije cakline fluor može biti učinkovit u remineralizaciji vanjskoga površinskog sloja koji je zapečaćen, onemogućujući tako prodiranje i popravljanje dubljih lezija cakline kalcijem i fosfatom (29). Uz to, smole za pečaćenje mogu samo porršinski prodrijeti u caklinske lezije jer nisu optimizirane za veliku prodornost (11). Budući da smole za pečaćenje fisura i tretman fluorom mogu utjecati samo na površinski dio lezije, ne može se spriječiti otapanje porozne strukture ispod površine koja djeluje kao difuzijski put za kiseline i minerale. Zato se tehnika infiltracije u početnim karijesnim lezijama s niskoviskoznom smolom smatra mikroinvazivnim preventivnim pristupom $(8,11,13)$.

Tehnika infiltracije smolom razvijena je kako bi se zaustavilo napredovanje karijesa ispunjavanjem porozne strukture početnih lezija svjetlosno očvrslom smolom niske viskoznosti (11). U usporedbi sa smolama za pečaćenje, infiltracijske smole imaju brzu kapilarnu penetraciju kao materijali niske viskoznosti koji tvore mali kontaktni kut s caklinom zbog svoje velike površinske energije $(3,11)$. Štoviše, suprotno činjenici da smole za pečaćenje ostaju samo na površini cakline kao difuzijska barijera, infiltracijske smole stvaraju difuzijsku barijeru u caklinskoj leziji i jačaju demineraliziranu strukturu cakline nadomještanjem izgubljenih minerala niskoviskoznom svjetlosno polimerizirajućom smolom $(6,11)$.

Učinkovitost infiltracije smolom u sprječavanju napredovanja karijesnih lezija na glatkim površinama istraživana je in vitro (30), in situ (31) i in vivo (32). Paris i suradnici (33) pokazali su mikroradiografskom tehnikom da niskoviskozna smola može inhibirati napredovanje prirodnih karijesnih lezija cakline glatke površine nakon 400 dana skladištenja pri $\mathrm{pH} 4,95$. Također su u drugom istraživanju izvijestili da je infiltracija smolom bila učinkovita u sprječavanju daljnje demineralizacije umjetnog karijesa na glatkoj površini cakline u kiselim uvjetima in situ (31). U istraživanju in vivo u kojemu se uspoređivao učinak infiltracije smolom aproksimalnih lezija s neoperativnim mjerama, pokazalo je da je infiltracija aproksimalnih karijesnih lezija učinkovito usporila napredovanje lezije (32). Budući da se u ranijim istraživanjima (6, 12, $30-33$ ) procjenjivao učinak samo na glatkim površinama, ti se rezultati ne mogu uspoređivati s rezultatima ovog istraživanja. Samo je u nekoliko istraživanja procjenjivana učinkovitost tehnike infiltracije smolom na okluzalnim površinama, a njihovi su autori procjenjivali samo prodor infiltracijskih smola $(13,14,34)$. Uz to, prema našem znanju, u nijednom istraživanju nije izvješteno o ponašanju infiltriranih lezija i učincima tankih slojeva smole na površinu lezije i susjednu zdravu caklinu.

U ovom je istraživanju, također SEM-om, procijenjena površinska morfologija uzoraka. U našem su istraživanju svi preventivni postupci bili učinkoviti u uklanjanju susjedne destruirane cakline na nekoj razini, u usporedbi $s$ kontrolnom skupinom. Metoda infiltracije smolom bila je pomak naprijed u smanjenju demineralizacije susjedne cakline u usporedbi s konvencionalnom smolom za pečaćenje i primjenom fluora jer je demineralizacija cakline bila mnogo blaža na SEM slici infiltriranog uzorka. To otkriće u skladu je s mnogobrojnim istraživanjima in vitro drugih autora $(11,13,14,27,34)$. 
All in vitro studies have some limitations. Likewise, the present study has a number of limitations. One limitation of this study was that laboratory tests could not precisely reflect clinical conditions. To reduce the influence of these factors, the $\mathrm{pH}$ cycling model was used in this experiment to effectively simulate the oral conditions leading to demineralization and remineralization that routinely occur in the oral environment. Another limitation is the lack of sagittal views of SEM evaluations, which would also help to interpret the subsurface element level results.

According to our findings and within the limitations of the present study, our hypothesis was partially confirmed. Being a microinvasive approach between preventive and restorative actions for the treatment of initial caries lesions on occlusal fissures, the resin infiltration technique could be a promising therapeutic method within the concept of minimum intervention dentistry. However, further in vitro and in vivo studies are needed to justify the use of such a protocol in clinical practice and assess the prognosis of infiltrated initial caries lesions under real oral conditions.

\section{Conclusion}

The subsurface demineralization preventing capability of resin infiltration technique, which was applied on initial demineralization of occlusal fissures, was comparable with conventional topical $\mathrm{F}$ and fissure sealant applications.

\section{Conflict of interest}

None declared

\section{Contribution to the paper}

S.A.H. performed the experiment, wrote the manuscript: E.E. wrote the idea, hypothesis, experimental design, performed some tests; A.O. performed statistical evaluation; S.G. worked on idea, experimental design, hypothesis and contributed substantially to discussion.
Sva istraživanja in vitro imaju određena ograničenja. Ovo istraživanje također ih uma. Jedno od njih je to što laboratorijski testovi ne mogu u cijelosti oponašati kliničke uvjete. Da bi se smanjio utjecaj tih čimbenika, u ovom je istraživanju korišten model cikliranja $\mathrm{pH}$ za učinkovitu simulaciju intraoralnih uvjeta koji dovode do procesa demineralizacije i remineralizacije tipičnih za oralno okružje. Drugo je ograničenje nedostatak sagitalnih presjeka na SEM evaluacije, što bi također pomoglo u tumačenju rezultata o razini elemenata ispod površine.

Prema našim nalazima i unutar ograničenja ovog istraživanja, naša je hipoteza djelomično potvrđena. Budući da je riječ o mikroinvazivnom pristupu između preventivnog i restaurativnog djelovanja u liječenju početnih karijesnih lezija u okluzalnim fisurama, tehnika infiltracije smolom mogla bi biti obećavajuća terapijska metoda u skladu s konceptom minimalne intervencijske stomatologije. No potrebna su daljnja istraživanja in vitro i in vivo kako bi se opravdala upotreba takvog protokola u kliničkoj praksi i procijenila prognoza infiltriranih početnih karijesnih lezija u stvarnim intraoralnim uvjetima.

\section{Zaključak}

Demineralizacija ispod površine pri infiltraciji smolom, koja je primijenjena na početnoj demineralizaciji okluzalnih fisura, može se usporediti $s$ uobičajenom topikalnom primjenom fluora i smole za pečaćenje fisura.

\section{Sukob interesa}

Autori nisu bili u sukobu interesa.

\section{Doprinos radu}

S. A. H. - osmislio eksperiment, napisao rukopis; E. E. - razradio ideju, postavio hipotezu, eksperimentalni dizajn, primijenio neke testove; A. O. - statistička analiza; S. G. radio na ideji, eksperimentalnom dizajnu, hipotezi te znatno pridonio raspravi.

\section{Sažetak}

Svrha rada: Usporedba gubitka minerala ispod površine koji sprječava svojstvo infiltracije smole s topikalnom primjenom fluora, te smole za pečaćenje fisura na demineralizirane okluzalne fisure u simuliranim oralnim uvjetima. Materijali i metode: Demineralizirane su okluzalne plohe 64 izvađena intaktna ljudska treća kutnjaka. Zatim su zubi klasificirani u četiri skupine prema preventivnoj tehnici $(\mathrm{n}=$ 16): G1 - uzorci koji su upotrijebljeni kao kontrolna skupina bez preventivnog liječenja; G2 - lokalna primjena fluorida (APF Gel/DEEPAK); G3 - primjena smole za pečaćenje fisura (ClinproTMSealant/3M ESPE); G4 - tehnika infiltracije smolom (Icon/DMG). Za osam uzoraka iz svake skupine analiziran je kemijski sastavi prije pH cikliranja. Preostalih osam zuba iz svake skupine podvrgnuto je cikliranju pH tijekom 15 dana kako bi se simulirali intraoralni uvjeti. Nakon toga uzorci su lomljeni nakon potapanja u tekući dušik te su rendgenskom spektrometrijom s energijskom disperzijom (EDS) izmjerene razine fluora $(\mathrm{F})$, kalcija $(\mathrm{Ca})$, fosfora $(\mathrm{P})$ i omjer $\mathrm{Ca} / \mathrm{P}$-a ispod površine svakog uzorka. Podatci su statistički analizirani $(p=0,05)$. Učinci preventivnih postupaka na površinsku topografiju uzoraka procijenjeni su s pomoću skenirajućeg elektronskog mikroskopa (SEM). Rezultati: Nije bilo značajnih razlika između skupina u razinama fluora, kalcija i fosfora te $\mathrm{u}$ omjerima $\mathrm{Ca} / \mathrm{P}$-a prije cikliranja $\mathrm{pH}$ i poslije toga postupka $(p>0,05)$. Prema opažanjima na SEM-u, sva tri preventivna postupka bila su učinkovita tijekom cikliranja pH. Zaključak: Svojstvo sprječavanja gubitaka minerala ispod površine moglo se usporediti tehnikom infiltracije smole koja se primjenjuje na okluzalnim fisurama i pri topikalnoj primjeni fluora i smole za pečaćenje fisura. Tehnika infiltracije smole mogla bi biti valjana alternativa tradicionalnim preventivnim i restaurativnim mjerama za liječenje početnih karijesnih lezija na okluzalnim fisurama zato što ima dvije prednosti - bolju infiltraciju i retenciju smole.
Zaprimljen: 8. veljače 2020 . Prihvaćen: 19. lipnja 2020.

Adresa za dopisivanje Sidika Aynur Horuztepe, DDS, PhD Specialist in Restorative Dentistry at EOT Dental Clinic, 06680 / Cankaya Ankara-TURKEY tel: +90 5336856625, faks: +903124274547 a.horuztepe@gmail.com

Ključne riječi demineralizacija zuba; materijali za pečaćenje fisura; topikalni fluoridi; stomatološke smole; koncentracija vodikovih iona 


\section{References}

1. Fejerskov O, Kidd EAM, editors. Dental caries: the disease and its clinical management. 2nd ed. Oxford: Blackwell Munksgaard; 2008.

2. Makhija SK, Gilber GH, Funkhouser E, Bader JD, Gordan VV, Rindal DB, et al. Characteristics, detection methods, and treatment of questionable occlusal carious lesions: findings from The National Dental Practice-Based Research Network. Caries Res. 2014;48(3):200-7.

3. Paris S, Meyer-Lueckel H, Kielbassa AM. Resin infiltration of natural caries lesions. J Dent Res. 2007 Jul;86(7):662-6.

4. Ritter, AV; Eidson, RS; Donovan, TE. Dental Caries: Etiology, Clinical Characteristics, Risk Assesment, and Management. In: Heymann, HO; Swift, JE; Ritter, AV - editors. Sturdevant's Art and Science of Operative Dentistry. 6th ed. St.Louis: Elsevier Mosby; 2013. p. 41-88.

5. Carvalho JC, Ekstrand KR, Thylstrup A. Dental plaque and caries on occlusal surfaces of first permanent molars in relation to stage of eruption. J Dent Res. 1989;68(5):773-9.

6. Meyer-Lueckel H, Paris S, Kielbassa AM. Surface layer erosion of natural caries lesions with phosphoric and hydrochloric acid gels in preparation for resin infiltration. Caries Res. 2007;41(3):223-30.

7. Wiegand A, Krieger C, Attin R, Hellwig E, Attin T. Fluoride uptake and resistance to further demineralisation of demineralised enamel after application of differently concentrated acidulated sodium fluoride gels. Clin Oral Investig. 2005 Mar;9(1):52-7.

8. Holmgren C, Gaucher C, Decerle N, Doméjean S. Minimal intervention dentistry II: part 3. Management of non-cavitated (initial) occlusal caries lesions - non-invasive approaches through remineralisation and therapeutic sealants. Br Dent J. 2014 Mar;216(5):237-43.

9. Anauate-Netto C, Borelli L, Amore R, DI Hipólito V, D’Alpino PH. Caries progression in non-cavitated fissures after infiltrant application: A 3-year follow-up of a randomized controlled clinical trial. J Appl Oral Sci. Jul-Aug 2017;25(4):442-454.

10. Griffin SO, Gray SK, Malvitz DM, Gooch BF. Caries risk in formerly sealed teeth. J Am Dent Assoc. 2009 Apr;140(4):415-23.

11. Kielbassa AM, Muller J, Gernhardt CR. Closing the gap between oral hygiene and minimally invasive dentistry: a review on the resin infiltration technique of incipient (proximal) enamel lesions. Quintessence Int. 2009 Sep;40(8):663-81.

12. Paris S, Meyer-Lueckel H, Cölfen H, Kielbassa AM. Resin infiltration of artificial enamel caries lesions with experimental light curing resins. Dent Mater J. 2007 Jul;26(4):582-8.

13. Paris S, Lausch J, Selje T, Dorfer CE, Meyer-Lueckel H. Comparison of sealant and infiltrant penetration into pit and fissure caries lesions in vitro. J Dent. $2014 \mathrm{Apr} ; 42(4): 432-8$

14. Paschos E. Sealant and infiltrant penetration into pit and fissure caries lesions: an in vitro comparison. J Orofac Orthop. 2014 Sep;75(5):328-33.

15. ten Cate JM, Duijsters PP. Alternating demineralization and remineralization of artificial enamel lesions. Caries Res. 1982;16(3):201-10.

16. White DJ. Reactivity of fluoride dentifrices with artificial caries. I. Effects on early lesions: $F$ uptake, surface hardening and remineralization. Caries Res. 1987;21(2):126-40.
17. Huang SB, Gao SS, Yu HY. Effect of nano-hydroxyapatite concentration on remineralization of initial enamel lesion in vitro. Biomed Mater. 2009 Jun;4(3):034104.

18. Pashley DH, Tay FR. Aggressiveness of contemporary self-etching adhesives. Part II: etching effects on unground enamel. Dent Mater. 2001 Sep;17(5):430-44.

19. Arends J, Christoffersen J. The nature of early caries lesions in enamel. J Dent Res 1986;65(1):2-11.

20. Eggerath J, Kremniczky T, Gaengler P, Arnold WH. EDX-Element Analysis of the In Vitro Effect of Fluoride Oral Hygiene Tablets on Artificial Caries Lesion Formation and Remineralization in Human Enamel. Open Dent J. 2011;5:84-9.

21. Abou Neel EA, Aljabo A, Strange A, et al. Demineralization-remineralization dynamics in teeth and bone. Int J Nanomedicine. 2016 Sep 19;11:4743-4763.

22. Eick JD, Robinson SJ, Byerley TJ, Chappell RP, Spencer P, Chappelow CC. Scanning transmission electron microscopy/energydispersive spectroscopy analysis of the dentin adhesive interface using a labeled 2-hydroxyethylmethacrylate analogue. Dent Res. 1995 Jun;74(6):1246-52.

23. Groeneveld A, Jongebloed W, Arends J. The mineral content of decalcified surface enamel. A combined microprobe- quantitative microradiography study. Caries Res. 1974;8(3):267-74.

24. Silverstone LM. The surface zone in caries and in caries-like lesions produced in vitro. Br Dent J. 1968 Aug 20;125(4):145-57.

25. Souza RO, Lombardo GH, Pereira SM. Analysis of tooth enamel after excessive bleaching: a study using scanning electron microscopy and energy dispersive x-ray spectroscopy. Int J Prosthodont. Jan-Feb 2010;23(1):29-32.

26. Scholz KJ, Federlin M, Hiller KA, Ebensberger H, Ferstl G, Buchalla W. EDX-analysis of fluoride precipitation on human enamel. Sci Rep. 2019 Sep 17;9(1):13442.

27. Gelani R, Zandona AF, Lippert F, Kamocka MM, Eckert G. In vitro progression of artificial white spot lesions sealed with an infiltrant resin. Oper Dent. Sep-Oct 2014;39(5):481-8.

28. Damato FA, Strang R, Stephen KW. Effect of fluoride concentration on remineralization of carious enamel: an in vitro $\mathrm{pH}$-cycling study. Caries Res. 1990;24(3):174-80.

29. Larsen MJ, Pearce El. Some notes on the diffusion of acidic and alkaline agents into natural human caries lesions in vitro. Arch Oral Biol. 1992;37(5):411-6.

30. Paris S, Meyer-Lueckel H. Infiltrants inhibit progression of natural caries lesions in vitro. J Dent Res. 2010 Nov;89(11):1276-80.

31. Paris S, Meyer-Lueckel H. Inhibition of caries progression by resin infiltration in situ. Caries Res. 2010;44(1):47-54.

32. Paris S, Hopfenmuller W, Meyer-Lueckel H. Resin infiltration of caries lesions: an efficacy randomized trial. J Dent Res. 2010 Aug;89(8):823-6.

33. Paris S, Meyer-Lueckel H, Colfen H, Kielbassa AM. Penetration coefficients of commercially available and experimental composites intended to infiltrate enamel carious lesions. Dent Mater. 2007 Jun;23(6):742-8.

34. Lausch J, Askar H, Paris S, Meyer-Lueckel H. Micro-filled resin infiltration of fissure caries lesions in vitro. J Dent. 2017 Feb;57:7376. 